\title{
Review
}

Journal of Innate

Immunity

\section{Cystic Fibrosis Lung Immunity: The Role of the Macrophage}

\author{
Emanuela M. Bruscia ${ }^{a} \quad$ Tracey L. Bonfield ${ }^{b}$ \\ a Section of Respiratory Medicine, Department of Pediatrics, Yale University School of Medicine, New Haven, Conn., \\ and ${ }^{b}$ Division of Pulmonology, Allergy and Immunology, Department of Pediatrics, Case Western Reserve University \\ School of Medicine, Cleveland, Ohio, USA
}

\section{Key Words}

Cystic fibrosis · Macrophages · Plasticity · Infection · Inflammation

\begin{abstract}
Cystic fibrosis (CF) pathophysiology is hallmarked by excessive inflammation and the inability to efficiently resolve lung infections, contributing to major morbidity and eventually the mortality of patients with this disease. Macrophages (MФs) are major players in lung homeostasis through their diverse contributions to both the innate and adaptive immune networks. The setting of MФ function and activity in $\mathrm{CF}$ is multifaceted, encompassing the response to the unique environmental cues in the CF lung as well as the intrinsic changes resulting from CFTR dysfunction. The complexity is further enhanced with the identification of modifier genes, which modulate the CFTR contribution to disease, resulting in epigenetic and transcriptional shifts in $M \Phi$ phenotype. This review focuses on the contribution of $M \Phi$ to lung homeostasis, providing an overview of the diverse literature and various perspectives on the role of these immune guardians in CF.

(c) 2016 S. Karger AG, Basel
\end{abstract}

Emanuela M. Bruscia and Tracey L. Bonfield contributed equally to this article.

\section{KARGER}

E-Mail karger@karger.com

www.karger.com/jin

\section{Role of Macrophages in Immunity}

Tissue macrophages (MФs) and blood-recruited monocytes have remarkable immune plasticity, with the ability to sense and adapt to the local milieu. МФ phenotype is defined by the surrounding environment, which ultimately is controlled by the host. These environmental contributions to $M \Phi$ plasticity, in turn, contribute to the efficiency and potency of their involvement in inflammation and host homeostasis including host defense, the initiation and resolution of inflammation, tissue repair and the removal of dead cells and tissue debris. The plasticity and phenotypic response to the environment has led to the description of M1 MФs and an entire series of M2 $M \Phi s$ with variable surface expression of scavenger receptors, pathogen recognition receptors, autoregulatory machinery and secretion of inflammatory/anti-inflammatory molecules [1].

In the lung, 2 major M $\Phi$ populations have been described: alveolar (AMs), which are located in the airway lumen, and interstitial, which reside in the lung parenchyma. The AMs, distinguished by their unique expres-

Dr. Emanuela M. Bruscia

Section of Respiratory Medicine, Department of Pediatrics

Yale University School of Medicine

330 Cedar Street, FMP, Room \#524, New Haven, CT 06520 (USA)

E-Mail emanuela.bruscia@yale.edu

Dr. Tracey L. Bonfield

Division of Pulmonology, Allergy and Immunology, Department of Pediatrics

Case Western Reserve University School of Medicine

10900 Euclid Avenue, Building \#822, Cleveland, OH 44106-4948 (USA)

E-Mail Tracey.Bonfield@ case.edu 
sion pattern (CD11c-pos; CD11b-neg), are the sentinels of the lung. They maintain immunological and physiological homoeostasis (e.g. the removal of debris and the recycling of surfactant molecules) and provide a first line of host defense [1]. They are inherently suppressive, in order to protect the lung from inflammation due to environmental perturbations. Once the $\mathrm{M} \Phi$ s are activated, they rapidly amplify the host response via the secretion of antimicrobials and proinflammatory mediators, by recruiting specialized phagocytes (e.g. neutrophils) and by communicating with other lung cells (e.g. alveolar cells [1]) for a rapid amplified response. The interstitial MФs (CD11c-low; CD11b-pos) are less characterized, being highly heterogeneous, with the potential for regulatory control. Indeed, it has been suggested that these MФs are major contributors to the production of cytokines (IL-10) associated with the adaptive immune response. During infections, activation of the proinflammatory process and release of neutrophil granule proteins (e.g. azurocin, LL37 and cathepsin $\mathrm{G}$ ) will trigger the recruitment of monocytes from the circulation, aiding in the fight against infection, the removal of dead cells and, eventually, the resolution of the ensuing lung inflammatory response [2].

MФs express a variety of receptors (plasma membrane or intracellular) and proteins which make them capable of sensing changes in the environment. These receptor interactions allow the $\mathrm{M} \Phi$ s to rapidly respond to the presence of microorganisms (e.g. bacteria, viruses and fungi), changes in physiology (e.g. changes in $\mathrm{pH}$, hypoxia and osmolarity), metabolite concentrations (e.g. ATP, fatty acids, heme, etc.) and extracellular matrix alterations (e.g. collagen degradation products and hyaluronic acid). When tissue homeostasis is perturbed, these receptors are activated, leading to a specific signaling transduction and the expression of mediators that will allow cross-talk with neighboring cells and the recruitment of immune cells which, together, will cooperate in reestablishing the lung status quo [3].

$M \Phi$ s sense microorganisms by recognizing pathogenassociated molecules or PAMPs, e.g. lipopolysaccharide (LPS), dsRNA and flagellin, through a repertoire of receptors called pattern-recognition receptors (PRRs). PRRs are expressed on immune and structural cells, including airway epithelium. They are divided into 4 major families: Toll-like receptors (TLRs), nucleotide oligomerization (NOD) receptors, c-type lectin receptors and retinoic acid-inducible gene 1 (RIG-I) receptors. Each of these receptor systems recognizes unique and diverse pathogenassociated molecules. PRRs are also activated by damaged cells that dump their cytoplasmic and nuclear compo-

Macrophages in CF Lung Disease nents (e.g. HMGBI, ATP and adenosine) into the extracellular milieu; these are the 'damage-associated molecular patterns' (DAMPs) of the inflammatory response. Once activated, PRRs, through a tightly regulated signal transduction mechanism, initiate the inflammatory response by producing inflammatory mediators, e.g. proinflammatory cytokines, reactive oxygen species (ROS), nitric oxide, carbon monoxide and antimicrobials, which lead to pathogen elimination, inflammation resolution and, eventually, the reestablishment of tissue homeostasis. Abundance, location, turnover and signal transduction regulation of these receptors will determine the quality, intensity and duration of the immune response [4].

In addition to external effector functions, $M \Phi$ s are also professional phagocytes, comprising the major mechanisms associated with the immune-regulated removal of pathogens, dead/dying cells and debris, and, in the case of AMs, are involved in surfactant homeostasis. Phagocytosis is a complex mechanism that involves an extraordinary cytoskeleton and plasma membrane reorganization, which allows $M \Phi$ chemotaxis and receptor-mediated binding to the inciting material to be phagocytized. Once internalized, elimination of the ingested material will be mediated by the fusion of phagosome with lysosomes. Thus, the $M \Phi$ ability to quickly remove microorganisms will depend on the activation of a complex transcriptional response, which encompasses cytoskeleton dynamics and vesicle trafficking/fusion, the production of lysosomal enzymes and the proton-pump acidification of lysosomal compartments. MФ PRRs and other plasma membrane receptors, such as complement $\mathrm{Fc}$ and scavenger receptors, contribute to binding and responding to invading microorganisms [2].

The extensive role of MФs in the pulmonary host response makes it an essential participant in lung homeostasis which, when dysfunctional, contributes to several human lung diseases including obstructive lung disease, asthma and allergic airways disease and fibrotic lung diseases [5].

\section{Monocyte/MФ Alterations in CF Are due to both Intrinsic and Acquired Factors}

The hypothesis that monocytes/MФs may contribute to CF lung disease was first proposed in 1982 [6]. CF MФ dysfunction was associated with altered activation defined by metabolic hyperactivity, with elevated production of proinflammatory cytokines [7], elastase [8] and tissue-damage mediators (termed ciliary dyskinesia sub- 
stances). These mediators impact airway epithelial-cell ciliary movements, contributing to the accumulation of mucus secretion [9]. Not until a few years later, with the discovery of the CFTR gene, was CFTR expression documented in MФs [10].

Several descriptive studies using МФs from CF patients have demonstrated that the $М \Phi$ phenotype changes during CF pathogenesis, as a result of plasticity. As already hypothesized 3 decades ago $[11,12]$, the CF lung environment (e.g. mucus, airway surface dehydration, increased protease activity, ROS, cytokines, etc.) plays a significant role in defining the phenotype of monocytes/ $\mathrm{M} \Phi$ s, such that their ability to properly regulate the inflammatory response, clear bacteria and favor lung tissue repair is altered. Furthermore, it has been documented that there is an increase in the absolute numbers of $M \Phi$ s in CF airways in the later stages of fetal development [13] and in young children with CF without detectable infection [14]. This increase has been correlated with elevated levels of the monocyte chemotactic protein 1 (MCP-1, also called CCL2) in the bronchoalveolar lavage fluid (BALF) and induced sputum from CF patients [14] and with lung exacerbations in patients with CF [15].

The remarkable ability of tissue MФs to adapt to the environment and carry out different functions led to their broad classification as either classically activated M1 $\mathrm{M} \Phi$ s, implicated in initiating and sustaining inflammation, or alternatively activated M2 MФs, associated with anti-inflammatory, immunoregulatory and tissue-repair properties. M2 MФs can also contribute to fibrotic pathology and allergic conditions [1]. In CF, the contribution of $M \Phi$ polarization to the lung disease is still unclear. In in vitro M2 cells, polarization is highly dependent on IL-4/1L-13 signaling and the production of high levels of arginase. Hartl et al. [16] reported that BALF from patients with CF infected with Pseudomonas aeruginosa had higher IL-4 and IL-13 concentrations and lower levels of IFN $-\gamma$ (an environment that favors M2 MФ polarization) compared with uninfected patients. Further, BALF levels of IL-4 and IL-13 correlated inversely with $\mathrm{FEV}_{1}$ [16]. Arginase activity, which has been postulated to be an important mediator of airway remodeling and lung fibrosis, has been shown to be elevated in CF lungs [17], with a concurrent, increased expression of mannose receptor (CD206). These markers of lung fibrosis have been correlated with a decline in pulmonary function in $P$. aeruginosa-infected CF patients [18]. Increased arginase activity has also been identified in the lung and airways of $C f t r$-deficient mice that is further augmented by infection with $P$. aeruginosa [19]. The CF lung environment is highly complex, concurrently demonstrating a proinflammatory phenotype, with high levels of IL-8, IL-6 and TNF- $\alpha$ and low levels of IL-10, an environment that would favor M1 MФ polarization instead [20, 21]. Furthermore, the expression of CD206 and other scavenger receptors (discussed later) has been found to be downregulated in sputum-derived MФs from CF patients [22], suggesting differences in the milieu of the lung and sputum. Animal studies have suggested that alveolar and peritoneal MФs from F508del CF mice exposed to LPS have elevated levels of both M1and M2 MФs compared to control Cftr-sufficient animals [23]. Thus, defining the contribution of $M \Phi$ polarization in CF lung disease may be challenging, since these cells dynamically adapt to the tissue environment and can vary with age, the status of lung disease, the bacterial flora and the therapeutic regimen that are unique to each patient.

The plasticity of the M $\Phi$ has made it difficult to completely appreciate the mechanisms associated with the changes in CF MФs [10]. The CFTR protein has been documented in murine [24-26], ferret [27] and human $[28,29]$ monocytes/MФs and associated with CFTR-like $\mathrm{Cl}^{-}$conductance abnormalities [28, 30,31]. Treatment of $M \Phi$ s with specific CFTR inhibitors have been shown to change the $M \Phi$ phenotype to resembles CF $M \Phi$ s, with an increased secretion of proinflammatory cytokines [24, 30]. LPS-induced hypersecretion of IL-8 has also been demonstrated utilizing peripheral blood (PB) monocytes isolated from subjects heterozygous for the F508del CFTR mutation compared to non-CF controls [32], further supported by the same observations with MФs isolated from heterozygous $C f t r$ mice [26]. Thus, a single allelic CFTR mutation is sufficient to augment proinflammatory activation in response to LPS in CF, implying CFTR-dependent defects in CF MФs.

\section{CF Monocytes/MФs Are Hyperinflammatory}

Cytokines such as TNF- $\alpha$, IL- $1 \beta$, IL- 6 and IL- 8 are elevated in the lungs of patients with CF compared with healthy controls, while the secretion of cytokines involved in resolution of inflammation, such as IL-10, is reduced $[20,21]$; this correlates with the expression in AMs and MФs. Further, treatments that improve clinical parameters in patients with CF, such as the antibiotic, azithromycin, have been found to reduce the proinflammatory phenotype in AMs [33], and $\mathrm{PB}$ monocytes respond to CFTR potentiator therapy (ivacaftor) in patients carrying the G551D mutation [34-36]. 
The proinflammatory behavior of MФs may be directly associated with chronic bacterial infection, which is constitutive once established in the lung of CF patients. In addition, the altered CF lung environment, which is rich in inflammatory mediators such ROS, HMGB1, neutrophil proteases and cellular matrix proteolytic products (e.g. proline-glycine-proline and hyaluronan fragments) [37], may persistently activate the PRRs in MФs (and other cell types in the lung) to optimize pathogen interaction and sensitivity as well as to stimulate proinflammatory pathways (e.g. NF- $\kappa \mathrm{B}$ and MAPK). Mucus obstruction and changes in airway surface hydration [38], the hallmark of CF lung disease, may also affect the ability of $\mathrm{M} \Phi$ s to properly respond to inflammatory triggers or efficiently phagocytose the pathogen invader.

In recent studies, it has been demonstrated that the robust production of inflammatory mediators in human CF AMs may be due the activation of the inositol-requiring enzyme 1 (IRE1)- $\alpha$-dependent X-box-binding protein-1 (XBP-1) arm of the unfolded protein response (UPR). These studies demonstrate higher mRNA levels of XBP-1 in CF when compared to non-CF AMs. This response seems to reflect an adaptation to the infectious/ inflammatory environment of $\mathrm{CF}$ airways rather than the loss of CFTR in CF MФs [39]. The factor in the CF lung milieu that contributes to this dysregulation is unknown.

Another observation, justified by a wealth of research, is that CF MФs are intrinsically hyperinflammatory. In support of this hypothesis, studies have demonstrated that in vitro cultures of $\mathrm{M} \Phi$ s isolated from the $\mathrm{PB}[30,32$, $40,41]$ of CF patients have an exaggerated inflammatory response to several inflammatory mediators. Consistent with the in vitro human data, MФs from CF mice and ferrets have also been shown to be proinflammatory [23, 25$27,30,41-43]$, with an increased production of proinflammatory cytokines when exposed to bacteria such as P. aeruginosa [42] and Burkholderia cepacia $[40,44,45]$ and PAMPs such as LPS [23, 25, 26] and flagellin [41]. Furthermore, studies in which bone marrow (BM) chimeras were made by transplanting wild-type and CF mice with either wild-type or CF BM, demonstrated the enhanced secretion of various proinflammatory cytokines after exposure to LPS. This demonstrates that the proinflammation may be related to MФs lacking functional CFTR rather than on the resident epithelial cells [26]. These data were consistent with studies on a model of $P$. aeruginosa infection using myeloid-specific Cftr knockout mice [42] and in $\mathrm{G}^{2} 51 \mathrm{D}^{-} / \mathrm{G} 51 \mathrm{D}^{-} \mathrm{CF}$ mice [46]. Thus, studies on animal models suggest that a loss of
CFTR in MФs/monocytes contributes to lung hyperinflammation in CF.

Since the identification of CF differences in response to pathogens, the search for how CFTR alters MФ function and activity has been ongoing. One potential hypothesis relates to the altered plasma membrane expression of immune receptors (i.e. TLR4 [30, 47] and TLR5 [48]) involved in immune signaling. In particular, the increased expression of TLR4, which is activated by LPS and also by DAMPs such as HMGB1, have been reported in murine [30] and human [30, 47] MФs. Furthermore, increased TLR4 levels lead to the sustained signal transduction and activation of the NF- $\kappa B$ and MAPK pathways, which induces a robust transcription of proinflammatory cytokines. The changes in TLR4 presence on the plasma membrane of CF MФs may be due to an abnormal internalization of the receptor in the endosomal compartment and the trafficking to the lysosomal compartment, where it is degraded, thus terminating signaling [30]. The endosomal defects contributing to the inefficient trafficking of TLRs may be related to observed abnormalities in the reduced expression of Rab proteins $[30,49]$ as well as the rate of microtubule formation [50], both of which contribute to vesicle trafficking, docking and maturation. CF cells, including $M \Phi s$, have altered levels of sphingolipids (e.g. ceramide) and cholesterol [51-53], which are key for shaping the signaling platform at the plasma membrane, called the lipid raft. CF МФs challenged with LPS also have impaired expression/distribution of the plasma membrane scaffolding-protein caveolin-1 [43], which facilitates the cellular transport of cholesterol to the plasma membrane in MФs [54]. Thus, low levels of caveolin-1 in CF MФs may affect the organization of lipid rafts during activation.

All these dysfunctions may have a tremendous impact on the regulation of immune receptor signaling.

The mechanisms mediating negative feedback of immune receptor signaling are also altered in CF MФs. CF $\mathrm{M \Phi s}$ have abnormal expression of nuclear receptors, such as peroxisome proliferator-activated receptors (PPARs) and liver X receptors (LXRs), which mediate fatty acid metabolism, a negative regulator of inflammation. MФs isolated from $\mathrm{Cftr}^{-/}$mice have low basal levels of PPAR $\gamma$ expression and attenuated LPS-driven induction of PPAR $\delta$ and LXRa [25]. Cellular distribution of the heme-oxygenase 1 (HO-1) protein, a key stress response protein involved in balancing cellular redox status and inflammation (including TLR4-negative regulation) is also altered in murine and human CF MФs exposed to LPS. In particular, HO-1 translocates to lipid rafts in a caveolin 1-dependent manner and catalyzes the local production of 
carbon monoxide (CO), which favors destabilization between TLR4 and its adaptor protein MyD88 (thus signaling termination), and this negative feedback mechanism is blunted in CF MФs [43]. In addition, in response to TLR-MyD88 activation, CF MФs display blunted PI3K/ AKT signaling [41], which normally plays a key role in regulating immune function [55] and in downregulating levels of microRNAs that amplify the TLR4 signaling (e.g. miR-155, let7e, miR-125b and miR199a-5p) in MФs.

Previous literature has suggested that both the mouse models of CF and the human disease have deficient autophagy mechanisms in their epithelial cells [56]. Autophagy is a conserved mechanism by which cells manage intracellular damage in order to maintain sustainability and efficiency. Furthermore, the process of autophagy allows for the recycling of membranes and cytosolic components for reuse. Deficiency in effective autophagy has been linked to a variety of diseases which have a part in the pathophysiology of chronic inflammation, including Crohn's disease and neutrodegeneration [57]. МФ autophagy has been well established as a mechanism of sustaining homeostasis [58], and when homeostasis is defective, this is linked to ineffective $M \Phi$ function [57]. Importantly, a proper autophagy flux in activated MФs has negative regulatory effects on TLR signaling, by controlling the signal transduction, trafficking and degradation of the receptor [57]. This autophagy dysfunction predisposes the CF MФs to the elevated production of proinflammatory cytokines during B. cepacia infection [40].

Finally, a lack of CFTR in monocytes affects the Rhosmall GTPase inside-out signaling trigged by monocyte/ $\mathrm{M} \Phi$ chemoattractant cytokines (e.g. MCP-1). This CFTRdependent defect has been found to impair $\beta-1$ and $\beta-2$ integrin-mediated monocyte adhesion and chemotaxis. As a consequence, monocytes lacking CFTR accumulated in the lung parenchyma and displayed blunted transmigration into the BAL space of wild-type mice intranasally treated with MCP-1 [35]. This incapability of CF monocytes to localize appropriately in different lung compartments in response to chemoattractants may very well affect both the inflammatory response and the host defense.

The mechanisms that could contribute to CF MФs hyperinflammatory behavior are summarized in figure 1a.

\section{CF MФs Display Inefficient Management of Infection}

Monocytes from CF patients have relatively low expression of the complement receptors urokinase-type plasminogen-activator receptor (uPAR) and CD11b, both important in facilitating the binding and phagocytosis of opsonized P. aeruginosa [29]. CF lungs also have pronounced expansion of small MФs with low expression of the scavenger receptors, CD206 and MARCO, involved in the binding and internalization of unopsonized particles as well as microbes [22]. Caveolin-1, which mediates $P$. aeruginosa internalization [59], is expressed at low levels in activated CF MФs [41, 43]. These observations suggest that monocytes/MФs in CF may have an impaired ability to properly phagocytose bacteria [29].

The CF environment also impacts the capability of CF $\mathrm{M} \Phi$ s to recognize and internalize bacteria [11] by altering signaling $[38,60]$ and cleaving the receptors necessary to orchestrate the adequate host-pathogen interaction. In particular, it has been found that elevated levels of neutrophil elastase in CF lungs cleave plasma membrane receptors/proteins such as complement proteins (e.g. C3, C5 and C3bi), complement receptors (e.g. CR1) and lymphocyte receptors (CD4 and CD8) [12]. Fick et al. [61], in 1981 , suggested that specific $P$. aeruginosa IgG in the serum and sputum of CF patients functioned in an inhibitory fashion, decreasing the efficiency of $P$. aeruginosa phagocytosis and intracellular killing. These early studies suggested that the Fab and Fc portions of the CF immunoglobulin molecule are impaired in their attachment to the alveolar MФ membrane Fc- $\gamma$ receptors, thus decreasing internalization. The phagocytic function of the complement receptors has also been shown to be defective in CF, with active elastase cleaving CR3 off the surface of phagocytes, contributing to inefficient infection resolution [62].

$\mathrm{M} \Phi$ s isolated from CF animal models (mice and ferrets) and CF patients also display an impaired capability for killing internalized bacteria, including $P$. aeruginosa and Burkholderia cenocepacia. Consistent with early studies that suggested a potential role for CFTR in maintaining a differential $\mathrm{pH}$ in the trans-Golgi, endosome and lysosome [63], Di et al. [24] proposed a mechanism by which a loss of CFTR in MФs is associated with the alkalization of the phagosomal lumen, which impairs $P$. aeruginosa killing. The working hypothesis is that CFTRmediated $\mathrm{Cl}^{-}$entry functions as counter-ion conductance to balance $\mathrm{H}^{+}$influx through V-ATPase in the lysosome, thereby maintaining an acidified lysosomal environment. These data were corroborated in MФs isolated from CF

Fig. 1. A summary of abnormalities described in CF MФs that lead to proinflammatory behavior (a) and suboptimal phagocytosis (b). Potential molecular mechanisms associated with these suboptimal performances are listed.

(For figure see next page.) 


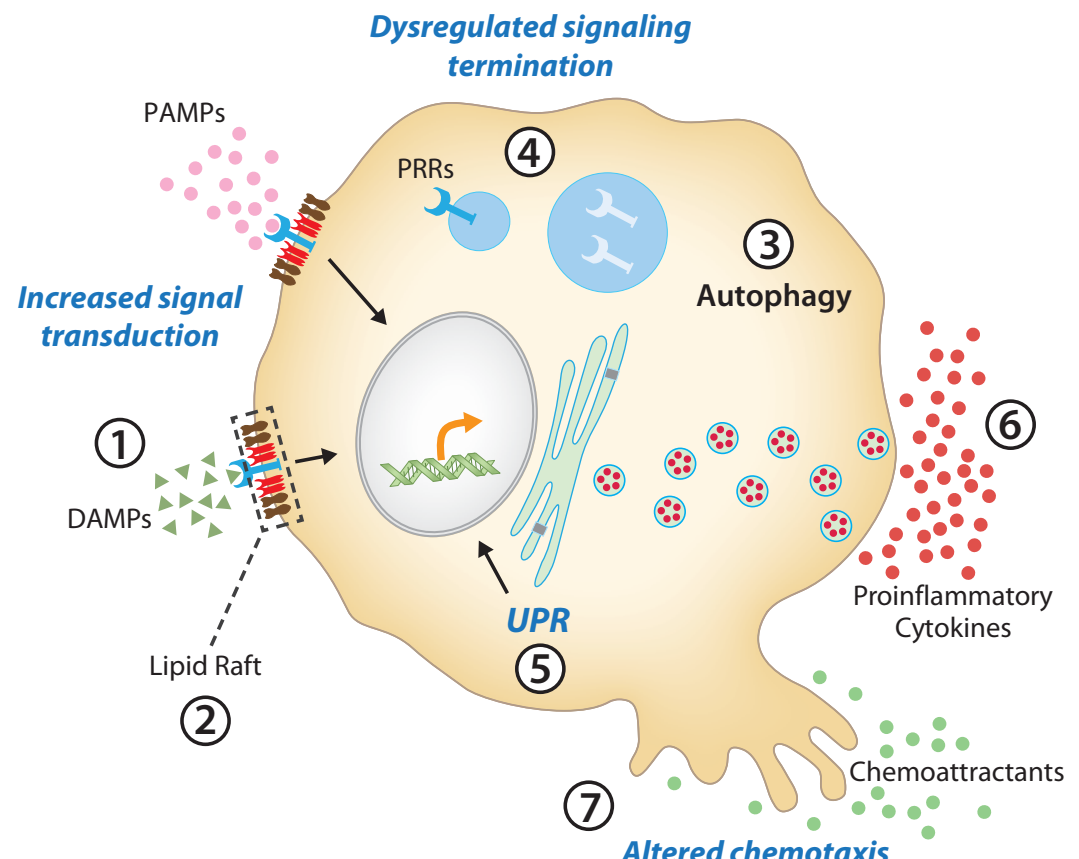

b CF MACROPHAGES ARE SUBOPTIMAL PHAGOCYTES

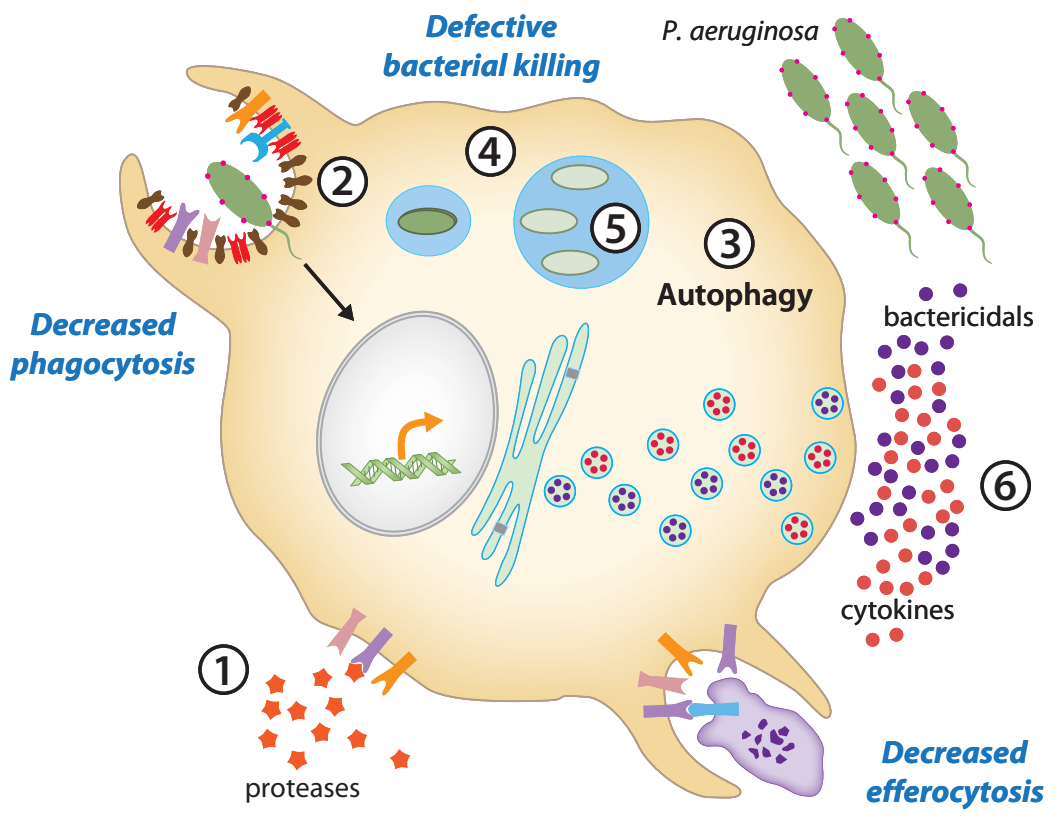

Mechanisms altered in CF MФs

1) Elevated levels of DAMPS in CF airways lead persisted immune receptor signalling

2) Abnormal lipid raft composition (e.g. altered distribution of cholesterol, sphingolipids and scaffolding proteins, which perturbs normal signal transduction regulation.)

3) Impaired autophagy affects TLR4 signal transduction.

4) Suboptimal vesicle trafficking, docking and maturation that impairs temporal and spatial localization of immune receptors, thus altering signalling intensity and duration. Altered Rab and SNARE protein expression and microtubule polarization may exacerbate this defect in CF.

5) Elevated activation of XBP-1 arm of the unfolded protein resonse (UPR).

6) PPARs - Dysregulation of PPAR results in constitutive NF-KB activation and cytokine production.

7) Altered chemotaxis affects $M \Phi$ localization in the lung.

\section{OUTPUT IN CF LUNG}

$\checkmark$ Increased secretion of proinflammatory mediators

$\checkmark$ Sustained hyperinflammation

$\checkmark$ Increase responsiveness to external stimuli

$\checkmark$ Inefficient waste management creating accumulation of damages and dysfunctional cellular products

Mechanisms altered in CF MФs

1) A high level of proteases in CF airway cleaves receptors (e.g. complement, Fc or scavenger receptors) on MФs or on corpus to be phagocytes (e.g. complement, find/eat-me signals, lgG).

2) Abnormal lipid raft composition perturbs engulfment of phagocytic corpus.

3) Impaired autophagy affects phagosome maturation.

4) Suboptimal vesicle trafficking, docking and maturation may alter phagolysosome formation and/or autophagy flux, which are both necessary for bacterial killing.

5) Altered lysosomal function (e.g. $\mathrm{pH}$ regulation and ROS formation).

6) Decreased production of bactericidal molecules (e.g. CO, lysozyme, etc.).

\section{OUTPUT IN CF LUNG}

$\checkmark$ Increased secretion of proinflammatory mediators

$\checkmark$ Bacterial survival and proliferation

$\checkmark$ Impaired initiation of the anti-inflammatory program

$\checkmark$ Impaired capacity for directing the resolution of either infection or inflammation 
patients [64] and in AMs from CF ferrets [27]. More recently, vesicle alkalization also been correlated with the failure of CF MФs to activate the acid sphingomyelinase enzyme, which is necessary for the formation of ceramideenriched membrane platforms [52]. The ceramide facilitates gp91phox-mediated oxidative burst in response to $P$. aeruginosa infection, promoting killing [52]. An altered mechanism of vesicle acidification in CF MФs was also proposed to favor intracellular survival of $B$. cenocepacia [44].

The major difficulty in all of these studies involving CFTR in lysosomal acidification has been the reproducibility of the observations, which has led to controversy about the theory of the dysfunctional lysosomal contribution of MФs to CF pathophysiology. It is likely that the differences are not a matter of right or wrong, but more likely due to the complexity of MФs and the exquisite sensitivity of the cell to minute changes in the environment of culture or purification $[65,66]$. While this controversy has not yet been resolved, an accurate comparison of studies suggests that defective vesicle acidification in CF MФs may depend on the complex cell signaling that is activated by $M \Phi$ s in response to live bacteria, which cannot be fully recapitulated when phagocytosis is mimicked with opsonized beads [44]. In any case, whether or not CFTR directly controls lysosomal $\mathrm{pH}$, a recent study suggests that drugs able to promote phagosome acidification, via potentiating the lysososmal activity of the transient receptor potential canonical-6 (TRPC6) calcium-permeable channel, can sufficiently restore microbicidal function in CF alveolar MФs [67].

As discussed previously, autophagy, a mechanism first described to be defective in CF epithelia [56], has more recently been directly linked to the ineffective bactericidal function of $\mathrm{M} \Phi$ s in CF. Indeed, deficient autophagy prevents destruction of B. cenocepacia in murine CF MФs $[45,68]$, and autophagy stimulation with rapamycin alleviates some of the dysfunction resulting in improved bacterial clearance of $B$. cenocepacia, $P$. aeruginosa and Staphylococcus aureus $[45,69,70]$. Unfortunately, rapamycin therapeutics are counter indicated for use in CF due to significant side effects, opening the door for therapeutic development targeting autophagy utilizing different drugs.

CF MФs might be defective in releasing bactericidal mediators that contribute to the extraordinary role of keeping the lungs sterile. For example, as discussed in the previous section, the plasma membrane trafficking of $\mathrm{HO}-1$ is blunted in activated CF MФs [43]. HO-1 catabolic products have strong immune-modulatory effects, and, importantly, by producing $\mathrm{CO}$, facilitate the killing of bacteria [71]. MФs produce high levels of antimicrobial enzymes (e.g. lasozyme) and a loss of CFTR may also interfere with this basic $М \Phi$ function. The mechanisms that compromise the bactericidal function of CF MФs are summarized in figure $1 \mathrm{~b}$.

\section{CF MФs Have Reduced Scavenger Ability}

$M \Phi$ scavenger function is altered by the $\mathrm{CF}$ environment (e.g. mucus, increased proteases, ROS, etc.). Apoptosis and efferocytosis are in tandem in maintaining tissue homeostasis, with disruption in interactions contributing to inefficient inflammation resolution and tissue destruction [72]. Alveolar MФs have been suggested to have deficient efferocytosis processes in a variety of diseases including CF [73]. The efficiency of the efferocytosis process is defined by $\mathrm{M} \Phi$ phenotype, with the $\mathrm{M} 1$ phenotype having little or no capacity for the process while the M2 phenotype has a high capacity for efferocytosis [74]. Much of the regulator process of efferocytosis goes back to the inverse relationships between PPAR $\gamma$ and NF- $\kappa B$ again regulating the phenotypic characteristic of the contribution of MФs to the inflammatory process. PPAR $\gamma$ drives the M2 phenotype whereas NF- $\kappa B$ drives the M1 phenotype [75]. The PPARs as retinoic acid-based lipid scavenger receptors are important in the process associated with surfactant and lipid metabolism [76]. Treatment of $\mathrm{Cftr}^{-/-}$AMs with endogenous PPAR $\gamma / \alpha$ ligands, including rosiglitazone (PPAR $\gamma$ ligand) or WY14643 (PPARa ligand) decreases the LPS-induced TNF- $\alpha$ response [25, 77]. As PPAR $\gamma$ has been shown to be important for the maturation and phagocytic capacity of MФs [78], these data would imply that the AM phenotype has the capacity to control proinflammatory cytokines via PPAR $\gamma$ in CF. The implication is that the change in the membrane lipids alters the functionality of the $\mathrm{M} \Phi \mathrm{s}$, which translates into inefficiency in both bacterial clearance and inflammation resolution. The role of these scavenger receptors is thought be important in the removal of foreign substances and waste materials that utilize extensive ligand specificity [79]. The absence of effective 'clean-up' and 'removal' systems can ultimately result in the accumulation of biologic waste, which interferes with homeostatic mechanisms. Therapeutic intervention aimed at improving scavenger receptor activity may provide support for the self-management of the unique milieu of the CF lung.

Removal of biologic waste in $\mathrm{M} \Phi$ s has been termed efferocytosis, which is the mechanism by which the MФs 
recognize phagocytes and dispose of apoptotic cells from the airway. However, elevated proteases in the CF lung alter efferocytosis efficiency. Proteases such as active elastase cleave MФ phosphatidylserine receptors; this impairs the capacity of $M \Phi$ s in the recognition and phagocytosis of apoptotic cells in CF lungs [12, 80] (fig. 1b). Removal of dying apoptotic cells is fundamental for the resolution of the inflammatory response [81]. Neutrophil phagocytosis by $M \Phi$ s triggers the production of mediators that curbs neutrophil migration and induces an antiinflammatory transcriptional program in the $М \Phi$ s (e.g. the expression of IL-10, lipoxins, resolvins, etc). In addition, it favors a high level of expression of scavenger receptors (e.g. CD206 and MARCO) that play a pivotal role in the binding and internalization of particles in the absence of opsonization, which reduces the responsiveness to TLR ligands [2]. In CF, small MФs with defects in the expression of CD206 and MARCO have been shown to be present in the CF airways (BALF and induced sputum) $[22,82]$. The lower expression of these receptors on MФs might contribute to an inability to properly clear inflammatory glycoproteins, oxidized lipids and inhaled particles that may be abundant in the damaged CF lung, thus enhancing the inflammation and tissue damage that is observed in the CF airways.

The $M \Phi$ products of the inflammatory response not only manage the infection but often contribute to tissue damage due to the potency of the agents such as reactive oxygen radicals, matrix metalloproteinases, cytokines and other protein-modifying agents [83]. Many of these products are produced through redirecting $M \Phi$ phenotype. Further recent data suggest that many of these changes can alter the $\mathrm{M} \Phi$ activation process, impacting inflammatory regulator pathways, activity and phenotype via epigenomic modification [75, 84]. Once the lung manages the intrusion, the healthy lung starts the reparative process, which includes reducing the inflammation by 'ramping up' anti-inflammatory molecules and protease-neutralizing agents as well as products potentially generated by the alveolar macrophage. Thus, M $\Phi$ abnormality in CF may perpetuate lung tissue scarring due to the inefficient activation of anti-inflammatory and repairing pathways.

\section{The CF Phagocyte and Adaptive Communication}

MФs, which can also function as professional antigenpresenting cells (APC), have been suggested to participate in redirecting downstream adaptive responses in CF [85,
86]. In these studies, shifting costimulatory molecules like CD80 and CD86 are suggested to alter T-cell reactivity and, potentially, the management of both infection and inflammation in CF. In this case, although the primary defect in the epithelial cells establishes the abnormal airway surface environment and initiates the pathophysiology that leads to progressive lung disease in $\mathrm{CF}$, changes in both adaptive and innate immunity exacerbate the disease pathophysiology associated with infection and inflammation resolution. The inability to resolve infection and attenuate inflammation downstream of infection plays a major role in the morbidity and mortality of the disease. Furthermore, improving the ability to manage exposure to pathogens and the relenting inflammatory process appears to be individualized, even within families that have the same CFTR mutation variant [87] or monozygotic twins [88]. The concept of genomic and environmental modifiers contributing to the complexity to $\mathrm{CF}$ pathophysiology provides a significant insight for therapeutic development and the understanding of the variability of the disease and its subsequent response to treatment.

Genome-wide association studies have begun to demonstrate that although the CFTR gene is the causative factor for the development of CF pathophysiology, there are certain associated genes that tend to correlate with the severity of CF disease $[89,90]$. Table 1 highlights some genes that are particularly relevant, specifically for how MФs may ultimately regulate the downstream adaptive control of inflammation and infection resolution. Alpha- 1 antitrypsin plays a role in innate immunity and has been the focus of studies in CF [91]. Bioactive mediators such as IL-10, C3, MIF, TGF- $\beta$, IFN- $\gamma$ and TNF- $\alpha$ have also been shown to correlate with some aspects of lung function or clinical exacerbations according to the comprehensive review by Weiler and Drumm [90].

The control of pathogen response is based upon effective immune defenses. The immune system is composed of multiple cell types which, together, improve the resistance against infections. Communication between APC or phagocytes such as MФs, their environment and downstream adaptive immunity is essential for an effective immune response. The studies of the CF genome-wide association project have shown that there is a significant correlation between MHC class II polymorphisms in the HLA-DR and HLA-DQ regions and overall disease severity $[89,92]$, implicating differences in the capacity to communicate to $\mathrm{T}$ cells and other adaptive immune cells. This is not unique to CF since there have been several instances of the association between specific MHC class II alleles and increased susceptibility or severity of inflam- 
Table 1. Variability in CF disease presentation has been shown to include both the genotype as well as environmental influences

\begin{tabular}{|c|c|c|c|}
\hline $\begin{array}{l}\text { Gene with } \\
\text { polymorphism }\end{array}$ & Function & $\mathrm{p}$ value & Clinical correlation \\
\hline $1 \mathrm{MHC}$ & antigen presentation & $\begin{array}{l}\leq 0.04 \text { onset of } \\
\text { colonization }\end{array}$ & $\begin{array}{l}\text { onset of pathogen colonization } \\
\text { frequency of colonization }\end{array}$ \\
\hline Alpha-1 antitrypsin & protease inhibition & 0.04 & $\mathrm{FEV}_{1} \%$ pred \\
\hline $\mathrm{ADRB} 2$ & alternative vs. classical MФs & $\leq 0.05$ & $\begin{array}{l}\mathrm{FEV}_{1} \% \text { pred } \\
5 \text {-year decline in pulmonary function }\end{array}$ \\
\hline CD14 & pathogen interactions & no association & disease severity \\
\hline DCTN4 & microtubule function & $\leq 0.05$ & $\begin{array}{l}\text { age at onset of chronic infection } \\
\text { age at first infection }\end{array}$ \\
\hline HLA & adaptive communication & $\leq 0.05$ & $\begin{array}{l}\mathrm{FEV}_{1} \% \text { pred } \\
\text { age at onset of chronic infection }\end{array}$ \\
\hline$\overline{\mathrm{IFN}}-\gamma$ & $\mathrm{M} \Phi$ activation & $\geq 0.09$ & $\begin{array}{l}\text { chronic infection: } P \text {. aeruginosa } \\
\text { age at death } \\
\text { age that } \mathrm{FEV}_{1} 50 \% \text { pred }\end{array}$ \\
\hline HMOX1 & transcriptional regulation & 0.01 & $\mathrm{FEV}_{1} \%$ pred \\
\hline IL-10 & immunoregulation & $\geq 0.02$ & $\begin{array}{l}\text { pulmonary function decline } \\
\text { age of } P \text {. aeruginosa infection } \\
\text { age at death }\end{array}$ \\
\hline NOS & immunoregulation & $\geq 0.02$ & $\begin{array}{l}\text { age at colonization } \\
\text { decline in pulmonary function }\end{array}$ \\
\hline TGF- $\beta$ & immunoregulation & $\leq 0.04$ & $\begin{array}{l}\text { age that } \mathrm{FEV}_{1} \leq 50 \% \text { pred } \\
\text { impairment of lung function }\end{array}$ \\
\hline TLR4 & pathogen interactions & $\geq 0.10$ & $\begin{array}{l}\text { rate of change of FEV } \\
\text { age at first infection }\end{array}$ \\
\hline TNF- $\alpha$ & inflammatory response & $\geq 0.02$ & $\begin{array}{l}\text { mean } \mathrm{FEV}_{1} \text { pred } \\
\text { mean Shwachman score } \\
\text { age at first infection }\end{array}$ \\
\hline
\end{tabular}

Recently, significant progress in genome-wide association studies has generated considerable interest in understanding other genes that might either enhance the CFTR-deficient phenotype or improve outcomes. This table provides a summary of the genes associated with $М \Phi$ function and clinical outcomes in CF patients.

matory diseases, including allergic bronchopulmonary aspergillosis, multiple sclerosis, rheumatoid arthritis, sarcoidosis, asthma and diabetes $[93,94]$. The interaction between $\mathrm{T}$ cells and MHC class II, along with the surrounding milieu, is crucial for defining the phenotype and success of the inflammatory response to infection. The host response to bacterial infection requires communication between APC and T cells [95]. This communication is relayed through MHC class II antigen presentation to helper T cells followed by adaptive T-cell or B-cell responses. Furthermore, the impact of HLA expression on $M \Phi$ s has the capacity to change downstream adaptive antigen presentation-dependent events, and decreased expression of HLA-DQ and HLA-DR is described in CF monocytes/MФs [96]. In traditional immunology, antigen presentation by APC, such as MФs and dendritic cells, results in adaptive networks including $\mathrm{T}$-cell immu- nity and B-cell activation [93]. Recently, it has become increasingly evident that B cells are not only responders to T-cell help, but, in exchange, are important programmers of the CD4 T-cell response including the priming and induction of T-cell memory [97]. In patients with CF, there is significant evidence supporting the concept of inefficient immune adaptive functions including the effector functions of NK cells [98], B cells [99] and T-cell abnormalities $[86,100]$ ultimately also contributing to the ineffective management of CF pathophysiology, which is directed by downstream communication circuits relayed through $M \Phi$ s and dendritic cells.

The interactions of $M \Phi s$ with other cells of the immune system also implicate them in changing downstream immune events. Dysfunctional epithelial cell function, the hallmark of $\mathrm{CF}$, and changes in $\mathrm{M} \Phi$ phenotype, can be complicated by the cross-talk between MФs and epithelial 


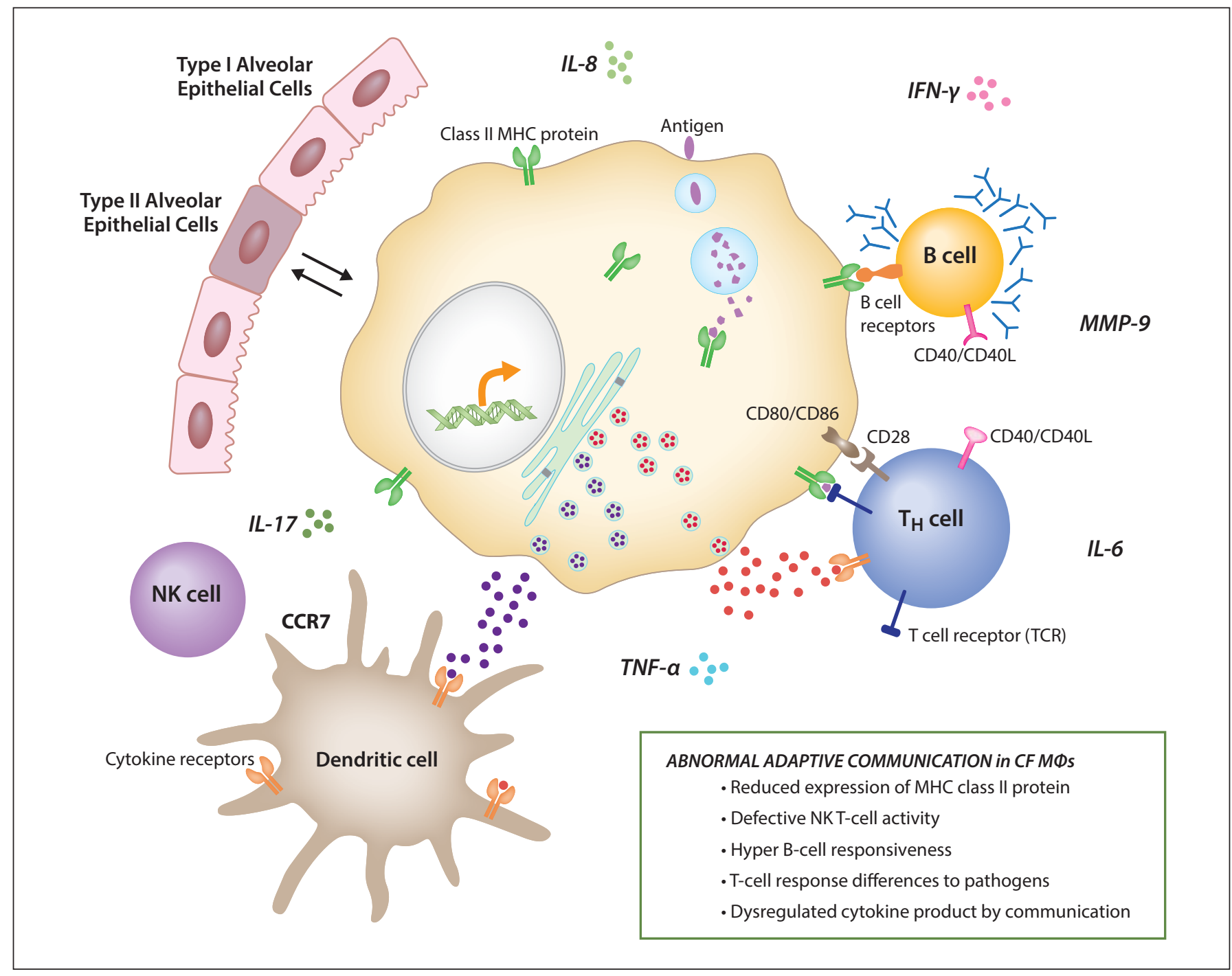

Fig. 2. The figure emphasizes the 'team' function of $M \Phi$ contribution to immune function and the potential contributions to $\mathrm{CF}$ lung pathophysiology. MФs, when dysfunctional, may not only alter their important role in healthy lung homeostasis, but also impact the surrounding immune community. T-cell communication networks through MФ MHC class II (defined by genomic correlations), with the potential of contributing to inefficient B-cell, T-cell and NK-cell activity, suggesting downstream pathophysiology associated with МФ dysfunction. cells [1]. MФs and respiratory epithelial cells can communicate via direct contact (the formation of gap junction channels), via cell surface receptors (e.g. CD200R and TGFBR) and via paracrine communication mediated by cytokines and microvesicles [1]. No knowledge is available regarding the potential dysregulation on MФs and respiratory epithelium cross-talk in CF. However, as highlighted in this review, the combined effects of immune cross-talk and the cellular immune artillery amplifies the role of $M \Phi s$ in the CF immune response to infection. Figure 2 demonstrates the hypothesis related to the diversity of the МФ phenotype and the impact that this may have not only on $М \Phi$ function but also on the function of the adaptive immune cells, which ultimately will relay the MФ message regarding the appropriate host response.

\section{Concluding Remarks: MФ Function and CF}

In summary, the innate immune response is altered in CF lungs, and monocytes/MФs are key contributors in orchestrating this process. The studies discussed in this 
review highlight that inherited (the loss of CFTR), as well as acquired factors (CF lung environment) affect the function of monocytes/MФs, so that they do not properly handle inflammatory triggers, they struggle to resolve inflammation and they fail to clear bacterial infection. In addition, $M \Phi s$ may improperly communicate with the other cells of the immune system, thus harming the adaptive immune response. Furthermore, the remarkable plasticity of $M \Phi$ s and the different $M \Phi$ subpopulations that can coexist complicate how these cells participate in CF lung pathophysiology, and our understating of these mechanisms is still in its infancy. Altogether, these studies support the notion that МФs contribute to CF lung pathology concomitantly with bronchial epithelium dysfunction.

Importantly, immune dysregulation represents a hallmark of the multiorgan manifestations in CF, such that hyperinflammation contributes to the destruction of the exocrine pancreas [101] and the tissue integrity of the gastrointestinal tract [102]. Thus, alterations in monocyte/M $\Phi$ function may contribute to CF manifestations beyond the lung disease.
As a prospective for the future, an effective, long-term therapy for CF should also modulate monocyte/MФ function, as has also been suggested in studies on patients treated with ivacaftor [34-36].

\section{Acknowledgements}

We thank the American Cystic Fibrosis Foundation (BRUSCI14G0 and BRUSCI15P0 to E.M.B. and BONFIE1410, BONFIE15XX0 to T.L.B.) and NIH (DK027651 and NIH-HL104362 to T.L.B.) for their support. We acknowledge the vast number of clinicians and researchers who have contributed to the study of МФs in CF. Our review did have a limitation on how many references could be used, so we apologize for not including any other manuscripts that could be perceived as supporting the review.

\section{Disclosure Statement}

The authors declare no conflict of interest.

\section{References}

1 Hussell T, Bell TJ: Alveolar macrophages: plasticity in a tissue-specific context. Nat Rev Immunol 2014;14:81-93.

-2 Soehnlein O, Lindbom L: Phagocyte partnership during the onset and resolution of inflammation. Nat Rev Immunol 2010;10:427439.

-3 Okabe Y, Medzhitov R: Tissue biology perspective on macrophages. Nat Immunol 2015; 17:9-17.

4 Pandey S, Kawai T, Akira S: Microbial sensing by Toll-like receptors and intracellular nucleic acid sensors. Cold Spring Harb Perspect Biol 2015; 7:a016246.

5 Byrne AJ, Mathie SA, Gregory LG, Lloyd CM: Pulmonary macrophages: key players in the innate defence of the airways. Thorax 2015; 70:1189-1196.

6 Wilson GB, Fudenberg HH: Does a primary host defense abnormality involving monocytes-macrophages underlie the pathogenesis of lung disease in cystic fibrosis? Med Hypotheses 1982;8:527-542.

7 Elborn JS, Norman D, Delamere FM, Shale DJ: In vitro tumor necrosis factor-alpha secretion by monocytes from patients with cystic fibrosis. Am J Respir Cell Mol Biol 1992;6: 207-211.
8 Jones MM, Seilheimer DK, Pier GB, Rossen $\mathrm{RD}$ : Increased elastase secretion by peripheral blood monocytes in cystic fibrosis patients. Clin Exp Immunol 1990;80:344-349.

-9 Wilson GB, Bahm VJ: Synthesis and secretion of cystic fibrosis ciliary dyskinesia substances by purified subpopulations of leukocytes. J Clin Invest 1980;66:1010-1019.

10 Yoshimura K, Nakamura H, Trapnell BC, Chu CS, Dalemans W, Pavirani A, Lecocq JP, Crystal RG: Expression of the cystic fibrosis transmembrane conductance regulator gene in cells of non-epithelial origin. Nucleic Acids Res 1991;19:5417-5423.

11 Thomassen MJ, Demko CA, Wood RE, Sherman JM: Phagocytosis of Pseudomonas aeruginosa by polymorphonuclear leukocytes and monocytes: effect of cystic fibrosis serum. Infect Immun 1982;38:802-805.

12 Doring G: The role of neutrophil elastase in chronic inflammation. Am J Respir Crit Care Med 1994;150: S114-S117.

13 Hubeau C, Puchelle E, Gaillard D: Distinct pattern of immune cell population in the lung of human fetuses with cystic fibrosis. J Allergy Clin Immunol 2001;108:524-529.

14 Brennan S, Sly PD, Gangell CL, Sturges N, Winfield K, Wikstrom M, Gard S, Upham JW, Arest CF: Alveolar macrophages and CC chemokines are increased in children with cystic fibrosis. Eur Respir J 2009;34:655-661.
15 Regamey N, Tsartsali L, Hilliard TN, Fuchs O, Tan HL, Zhu J, Qiu YS, Alton EW, Jeffery PK, Bush A, Davies JC: Distinct patterns of inflammation in the airway lumen and bronchial mucosa of children with cystic fibrosis. Thorax 2012;67:164-170.

16 Hartl D, Griese M, Kappler M, Zissel G, Reinhardt D, Rebhan C, Schendel DJ, KraussEtschmann S: Pulmonary $\mathrm{T}(\mathrm{h}) 2$ response in Pseudomonas aeruginosa-infected patients with cystic fibrosis. J Allergy Clin Immunol 2006;117:204-211.

17 Grasemann H, Schwiertz R, Matthiesen S, Racke K, Ratjen F: Increased arginase activity in cystic fibrosis airways. Am J Respir Crit Care Med 2005;172:1523-1528.

-18 Murphy BS, Bush HM, Sundareshan V, Davis C, Hagadone J, Cory TJ, Hoy H, Hayes D Jr, Anstead MI, Feola DJ: Characterization of macrophage activation states in patients with cystic fibrosis. J Cyst Fibros 2010;9:314-322.

19 Jaecklin T, Duerr J, Huang H, Rafii M, Bear CE, Ratjen F, Pencharz P, Kavanagh BP, Mall MA, Grasemann H: Lung arginase expression and activity is increased in cystic fibrosis mouse models. J Appl Physiol (1985) 2014; 117:284-288 
20 Bonfield TL, Konstan MW, Burfeind P, Panuska JR, Hilliard JB, Berger M: Normal bronchial epithelial cells constitutively produce the anti-inflammatory cytokine interleukin-10, which is downregulated in cystic fibrosis. Am J Respir Cell Mol Biol 1995;13: 257-261.

-21 Bonfield TL, Panuska JR, Konstan MW, Hilliard KA, Hilliard JB, Ghnaim H, Berger M: Inflammatory cytokines in cystic fibrosis lungs. Am J Respir Crit Care Med 1995;152: 2111-2118.

22 Wright AK, Rao S, Range S, Eder C, Hofer TP, Frankenberger M, Kobzik L, Brightling C, Grigg J, Ziegler-Heitbrock L: Pivotal advance: expansion of small sputum macrophages in CF: failure to express MARCO and mannose receptors. J Leukoc Biol 2009;86:479-489.

-23 Meyer M, Huaux F, Gavilanes X, van den Brule S, Lebecque P, Lo Re S, Lison D, Scholte $B$, Wallemacq P, Leal T: Azithromycin reduces exaggerated cytokine production by $\mathrm{M} 1 \mathrm{al}-$ veolar macrophages in cystic fibrosis. Am J Respir Cell Mol Biol 2009;41:590-602.

-24 Di A, Brown ME, Deriy LV, Li C, Szeto FL, Chen Y, Huang P, Tong J, Naren AP, Bindokas V, Palfrey HC, Nelson DJ: CFTR regulates phagosome acidification in macrophages and alters bactericidal activity. Nat Cell Biol 2006; 8:933-944.

-25 Andersson C, Zaman MM, Jones AB, Freedman SD: Alterations in immune response and PPAR/LXR regulation in cystic fibrosis macrophages. J Cyst Fibros 2008;7:68-78.

26 Bruscia EM, Zhang PX, Ferreira E, Caputo C, Emerson JW, Tuck D, Krause DS, Egan ME: Macrophages directly contribute to the exaggerated inflammatory response in cystic fibrosis transmembrane conductance regulator $^{-/-}$mice. Am J Respir Cell Mol Biol 2009; 40:295-304.

27 Keiser N, Gabdoulkhakova A, Riazanski V, Nelson D, Engelhardt J: Ferret alveolar macrophage function is dependent on CFTR. Pediatr Pulmonol 2014;49:278-279.

-28 Sorio C, Buffelli M, Angiari C, Ettorre M, Johansson J, Vezzalini M, Viviani L, Ricciardi M, Verze G, Assael BM, Melotti P: Defective CFTR expression and function are detectable in blood monocytes: development of a new blood test for cystic fibrosis. PLoS One 2011; 6:e22212.

29 van de Weert-van Leeuwen PB, van Meegen MA, Speirs JJ, Pals DJ, Rooijakkers SH, Van der Ent CK, Terheggen-Lagro SW, Arets HG, Beekman JM: Optimal complement-mediated phagocytosis of Pseudomonas aeruginosa by monocytes is CFTR-dependent. Am J Respir Cell Mol Biol 2013;49:463-470.

30 Bruscia EM, Zhang PX, Satoh A, Caputo C, Medzhitov R, Shenoy A, Egan ME, Krause DS: Abnormal trafficking and degradation of TLR4 underlie the elevated inflammatory response in cystic fibrosis. J Immunol 2011;186: 6990-6998.
1 Shenoy A, Kopic S, Murek M, Caputo C, Geibel JP, Egan ME: Calcium-modulated chloride pathways contribute to chloride flux in murine CF-affected macrophages. Pediatr Res 2011;70:447-452.

32 Zaman MM, Gelrud A, Junaidi O, Regan MM, Warny M, Shea JC, Kelly C, O'Sullivan BP, Freedman SD: Interleukin 8 secretion from monocytes of subjects heterozygous for the deltaF508 cystic fibrosis transmembrane conductance regulator gene mutation is altered. Clin Diagn Lab Immunol 2004;11:819-824.

33 Cory TJ, Birket SE, Murphy BS, Hayes D Jr, Anstead MI, Kanga JF, Kuhn RJ, Bush HM, Feola DJ: Impact of azithromycin treatment on macrophage gene expression in subjects with cystic fibrosis. J Cyst Fibros 2014;13: 164-171.

34 Bratcher PE, Rowe SM, Reeves G, Roberts T, Szul T, Harris WT, Tirouvanziam R, Gaggar A: Alterations in blood leukocytes of G551Dbearing cystic fibrosis patients undergoing treatment with ivacaftor. J Cyst Fibros 2016; 15:67-73.

35 Sorio C, Montresor A, Bolomini-Vittori M, Caldrer S, Rossi B, Dusi S, Angiari S, Johansson JE, Vezzalini M, Leal T, Calcaterra E, Assael BM, Melotti P, Laudanna C: Mutations of cystic fibrosis transmembrane conductance regulator (CFTR) gene cause a monocyte-selective adhesion deficiency. Am J Respir Crit Care Med 2016;193:1123-1133.

-36 Hisert KB, Schoenfelt KQ, Cooke G, Grogan B, Launspach JL, Gallagher CG, Donnelly SC, Welsh MJ, Singh PK, McKone EF, Becker L: Ivacaftor-induced proteomic changes suggest monocyte defects may contribute to the pathogenesis of cystic fibrosis. Am J Respir Cell Mol Biol 2016;54:594-597.

37 Cantin AM, Hartl D, Konstan MW, Chmiel JF: Inflammation in cystic fibrosis lung disease: pathogenesis and therapy. J Cyst Fibros 2015;14:419-430

- 38 Saini Y, Dang H, Livraghi-Butrico A, Kelly EJ, Jones LC, O'Neal WK, Boucher RC: Gene expression in whole lung and pulmonary macrophages reflects the dynamic pathology associated with airway surface dehydration. BMC Genomics 2014;15:726.

- 39 Lubamba BA, Jones LC, O’Neal WK, Boucher RC, Ribeiro CM: X-box-binding protein 1 and innate immune responses of human cystic fibrosis alveolar macrophages. Am J Respir Crit Care Med 2015;192:1449-1461.

40 Kopp BT, Abdulrahman BA, Khweek AA, Kumar SB, Akhter A, Montione R, Tazi MF, Caution K, McCoy K, Amer AO: Exaggerated inflammatory responses mediated by Burkholderia cenocepacia in human macrophages derived from cystic fibrosis patients. Biochem Biophys Res Commun 2012;424:221-227.

41 Zhang PX, Cheng J, Zou S, D’Souza AD, Koff JL, Lu J, Lee PJ, Krause DS, Egan ME, Bruscia EM: Pharmacological modulation of the AKT/ microRNA-199a-5p/CAV1 pathway ameliorates cystic fibrosis lung hyper-inflammation. Nat Commun 2015;6:6221.
42 Bonfield TL, Hodges CA, Cotton CU, Drumm ML: Absence of the cystic fibrosis transmembrane regulator (CFTR) from myeloid-derived cells slows resolution of inflammation and infection. J Leukoc Biol 2012;92:11111122.

43 Zhang PX, Murray TS, Villella VR, Ferrari E, Esposito S, D’Souza A, Raia V, Maiuri L, Krause DS, Egan ME, Bruscia EM: Reduced caveolin-1 promotes hyperinflammation due to abnormal heme oxygenase- 1 localization in lipopolysaccharide-challenged macrophages with dysfunctional cystic fibrosis transmembrane conductance regulator. J Immunol 2013;190:5196-5206.

44 Lamothe J, Valvano MA: Burkholderia cenocepacia-induced delay of acidification and phagolysosomal fusion in cystic fibrosis transmembrane conductance regulator (CFTR)-defective macrophages. Microbiology $2008 ; 154: 3825-3834$.

45 Abdulrahman BA, Khweek AA, Akhter A, Caution K, Kotrange S, Abdelaziz DH, Newland C, Rosales-Reyes R, Kopp B, McCoy K, Montione R, Schlesinger LS, Gavrilin MA, Wewers MD, Valvano MA, Amer AO: Autophagy stimulation by rapamycin suppresses lung inflammation and infection by Burkholderia cenocepacia in a model of cystic fibrosis. Autophagy 2011;7:1359-1370.

46 Oceandy D, McMorran BJ, Smith SN, Schreiber R, Kunzelmann K, Alton EW, Hume DA, Wainwright BJ: Gene complementation of airway epithelium in the cystic fibrosis mouse is necessary and sufficient to correct the pathogen clearance and inflammatory abnormalities. Hum Mol Genet 2002; 11:1059-1067.

-47 Sturges NC, Wikstrom ME, Winfield KR, Gard SE, Brennan S, Sly PD, Upham JW: Monocytes from children with clinically stable cystic fibrosis show enhanced expression of Toll-like receptor 4. Pediatr Pulmonol 2010;45:883-889.

48 Simonin-Le Jeune K, Le Jeune A, Jouneau S, Belleguic C, Roux PF, Jaguin M, DimancheBoitre MT, Lecureur V, Leclercq C, Desrues $B$, Brinchault G, Gangneux JP, Martin-Chouly C: Impaired functions of macrophage from cystic fibrosis patients: CD11b, TLR-5 decrease and sCD14, inflammatory cytokines increase. PLoS One 2013;8:e75667.

49 Kelly C, Canning P, Buchanan PJ, Williams MT, Brown V, Gruenert DC, Elborn JS, Ennis $\mathrm{M}$, Schock BC: Toll-like receptor 4 is not targeted to the lysosome in cystic fibrosis airway epithelial cells. Am J Physiol Lung Cell Mol Physiol 2013;304:L371-L382.

50 Rymut SM, Ivy T, Corey DA, Cotton CU, Burgess JD, Kelley TJ: Role of exchange protein activated by cAMP 1 in regulating rates of $\mathrm{mi}-$ crotubule formation in cystic fibrosis epithelial cells. Am J Respir Cell Mol Biol 2015;53: 853-862. 
-51 Hamai H, Keyserman F, Quittell LM, Worgall TS: Defective CFTR increases synthesis and mass of sphingolipids that modulate membrane composition and lipid signaling. J Lipid Res 2009;50:1101-1108.

-52 Zhang Y, Li X, Grassme H, Doring G, Gulbins E: Alterations in ceramide concentration and $\mathrm{pH}$ determine the release of reactive oxygen species by CFTR-deficient macrophages on infection. J Immunol 2010;184:5104-5111.

- 53 White NM, Jiang D, Burgess JD, Bederman IR, Previs SF, Kelley TJ: Altered cholesterol homeostasis in cultured and in vivo models of cystic fibrosis. Am J Physiol Lung Cell Mol Physiol 2007;292:L476-L486.

54 Gargalovic P, Dory L: Caveolins and macrophage lipid metabolism. J Lipid Res 2003;44: $11-21$.

-55 Androulidaki A, Iliopoulos D, Arranz A, Doxaki C, Schworer S, Zacharioudaki V, Margioris AN, Tsichlis PN, Tsatsanis C: The kinase Aktl controls macrophage response to lipopolysaccharide by regulating microRNAs. Immunity 2009;31:220-231.

-56 Luciani A, Villella VR, Esposito S, BrunettiPierri N, Medina D, Settembre C, Gavina M, Pulze L, Giardino I, Pettoello-Mantovani M, D’Apolito M, Guido S, Masliah E, Spencer B, Quaratino S, Raia V, Ballabio A, Maiuri L: Defective CFTR induces aggresome formation and lung inflammation in cystic fibrosis through ROS-mediated autophagy inhibition. Nat Cell Biol 2010;12:863-875.

-57 Deretic V, Kimura T, Timmins G, Moseley P, Chauhan S, Mandell M: Immunologic manifestations of autophagy. J Clin Invest 2015; 125:75-84.

58 Amer AO, Byrne BG, Swanson MS: Macrophages rapidly transfer pathogens from lipid raft vacuoles to autophagosomes. Autophagy 2005;1:53-58.

-59 Bajmoczi M, Gadjeva M, Alper SL, Pier GB, Golan DE: Cystic fibrosis transmembrane conductance regulator and caveolin-1 regulate epithelial cell internalization of Pseudomonas aeruginosa. Am J Physiol Cell Physiol 2009;297:C263-C277.

-60 Bessich JL, Nymon AB, Moulton LA, Dorman $\mathrm{D}$, Ashare A: Low levels of insulin-like growth factor-1 contribute to alveolar macrophage dysfunction in cystic fibrosis. J Immunol 2013;191:378-385.

61 Fick RB Jr, Naegel GP, Matthay RA, Reynolds HY: Cystic fibrosis pseudomonas opsonins. Inhibitory nature in an in vitro phagocytic assay. J Clin Invest 1981;68:899-914.

-62 Tosi MF, Zakem H, Berger M: Neutrophil elastase cleaves C3bi on opsonized Pseudomonas as well as CR1 on neutrophils to create a functionally important opsonin receptor mismatch. J Clin Invest 1990;86:300-308.

-63 Barasch J, Kiss B, Prince A, Saiman L, Gruenert D, al-Awqati Q: Defective acidification of intracellular organelles in cystic fibrosis. Nature 1991;352:70-73.
64 Del Porto P, Cifani N, Guarnieri S, Di Domenico EG, Mariggio MA, Spadaro F, Guglietta S, Anile M, Venuta F, Quattrucci S, Ascenzioni F: Dysfunctional CFTR alters the bactericidal activity of human macrophages against Pseudomonas aeruginosa. PLoS One 2011;6:e19970.

65 Haggie PM, Verkman AS: Cystic fibrosis transmembrane conductance regulator-independent phagosomal acidification in macrophages. J Biol Chem 2007;282:31422-31428.

66 Barriere H, Bagdany M, Bossard F, Okiyoneda T, Wojewodka G, Gruenert D, Radzioch D, Lukacs GL: Revisiting the role of cystic fibrosis transmembrane conductance regulator and counterion permeability in the $\mathrm{pH}$ regulation of endocytic organelles. Mol Biol Cell 2009;20:3125-3141.

67 Riazanski V, Gabdoulkhakova AG, Boynton LS, Eguchi RR, Deriy LV, Hogarth DK, Loaec $\mathrm{N}$, Oumata $\mathrm{N}$, Galons $\mathrm{H}$, Brown ME, Shevchenko P, Gallan AJ, Yoo SG, Naren AP, Villereal ML, Beacham DW, Bindokas VP, Birnbaumer L, Meijer L, Nelson DJ: TRPC6 channel translocation into phagosomal membrane augments phagosomal function. Proc Natl Acad Sci USA 2015;112:E6486-E6495.

68 Abdulrahman BA, Khweek AA, Akhter A, Caution K, Tazi M, Hassan H, Zhang Y, Rowland PD, Malhotra S, Aeffner F, Davis IC, Valvano MA, Amer AO: Depletion of the ubiquitin-binding adaptor molecule SQSTM1/p62 from macrophages harboring cftr $\Delta \mathrm{F} 508 \mathrm{mu}$ tation improves the delivery of Burkholderia cenocepacia to the autophagic machinery. J Biol Chem 2013;288:2049-2058.

69 Yuan K, Huang C, Fox J, Laturnus D, Carlson E, Zhang B, Yin Q, Gao H, Wu M: Autophagy plays an essential role in the clearance of Pseudomonas aeruginosa by alveolar macrophages. J Cell Sci 2012;125:507-515.

70 Schnaith A, Kashkar H, Leggio SA, Addicks K, Kronke M, Krut O: Staphylococcus aureus subvert autophagy for induction of caspaseindependent host cell death. J Biol Chem 2007;282:2695-2706

71 Wegiel B, Larsen R, Gallo D, Chin BY, Harris C, Mannam P, Kaczmarek E, Lee PJ, Zuckerbraun BS, Flavell R, Soares MP, Otterbein LE: Macrophages sense and kill bacteria through carbon monoxide-dependent inflammasome activation. J Clin Invest 2014;124:4926-4940.

72 Vandivier RW, Henson PM, Douglas IS: Burying the dead: the impact of failed apoptotic cell removal (efferocytosis) on chronic inflammatory lung disease. Chest 2006;129: 1673-1682.

73 Soleti R, Porro C, Martinez MC: Apoptotic process in cystic fibrosis cells. Apoptosis 2013;18:1029-1038.

74 McCubbrey AL, Curtis JL: Efferocytosis and lung disease. Chest 2013;143:1750-1757.

75 Croasdell A, Duffney PF, Kim N, Lacy SH, Sime PJ, Phipps RP: PPAR $\gamma$ and the innate immune system mediate the resolution of inflammation. PPAR Res 2015;2015:549691.
76 Bonfield TL, Farver CF, Barna BP, Malur A, Abraham S, Raychaudhuri B, Kavuru MS, Thomassen MJ: Peroxisome proliferator-activated receptor-gamma is deficient in alveolar macrophages from patients with alveolar proteinosis. Am J Respir Cell Mol Biol 2003;29: 677-682.

77 Ollero M, Junaidi O, Zaman MM, Tzameli I, Ferrando AA, Andersson C, Blanco PG, Bialecki E, Freedman SD: Decreased expression of peroxisome proliferator activated receptor gamma in cftr-/- mice. J Cell Physiol 2004; 200:235-244.

78 Majai G, Sarang Z, Csomos K, Zahuczky G, Fesus L: PPAR $\gamma$-dependent regulation of human macrophages in phagocytosis of apoptotic cells. Eur J Immunol 2007;37:13431354.

79 Roszer T: Understanding the mysterious M2 macrophage through activation markers and effector mechanisms. Mediators Inflamm 2015;2015:816460.

-80 Vandivier RW, Fadok VA, Hoffmann PR, Bratton DL, Penvari C, Brown KK, Brain JD, Accurso FJ, Henson PM: Elastase-mediated phosphatidylserine receptor cleavage impairs apoptotic cell clearance in cystic fibrosis and bronchiectasis. J Clin Invest 2002;109:661670.

81 Poon IK, Lucas CD, Rossi AG, Ravichandran KS: Apoptotic cell clearance: basic biology and therapeutic potential. Nat Rev Immunol 2014;14:166-180.

82 Garratt LW, Wright AK, Ranganathan SC, Grigg J, Sly PD; behalf of AC. Small macrophages are present in early childhood respiratory disease. J Cyst Fibros 2012;11:201-208.

$83 \mathrm{Haq}$ IJ, Gray MA, Garnett JP, Ward C, Brodlie M: Airway surface liquid homeostasis in cystic fibrosis: pathophysiology and therapeutic targets. Thorax 2016;71:284-287.

84 Bergougnoux A, Claustres M, De Sario A: Nasal epithelial cells: a tool to study DNA methylation in airway diseases. Epigenomics 2015; 7:119-126.

85 Soltys J, Bonfield T, Chmiel J, Berger M: Functional IL-10 deficiency in the lung of cystic fibrosis $\left(\mathrm{cftr}^{-/-}\right)$and IL-10 knockout mice causes increased expression and function of B7 costimulatory molecules on alveolar macrophages. J Immunol 2002;168:1903-1910.

-86 Mueller C, Braag SA, Keeler A, Hodges C, Drumm M, Flotte TR: Lack of cystic fibrosis transmembrane conductance regulator in CD3+ lymphocytes leads to aberrant cytokine secretion and hyperinflammatory adaptive immune responses. Am J Respir Cell Mol Biol 2011;44:922-929.

87 Collaco JM, Blackman SM, McGready J, Naughton KM, Cutting GR: Quantification of the relative contribution of environmental and genetic factors to variation in cystic fibrosis lung function. J Pediatr 2010;157:802-807. e1-e3. 
88 Cutting GR: Modifier genes in Mendelian disorders: the example of cystic fibrosis. Ann NY Acad Sci 2010;1214:57-69.

89 Wright FA, Strug LJ, Doshi VK, Commander CW, Blackman SM, Sun L, Berthiaume Y, Cutler D, Cojocaru A, Collaco JM, Corey M, Dorfman R, Goddard K, Green D, Kent JW Jr, Lange EM, Lee S, Li W, Luo J, Mayhew GM, Naughton KM, Pace RG, Pare P, Rommens JM, Sandford A, Stonebraker JR, Sun W, Taylor C, Vanscoy LL, Zou F, Blangero J, Zielenski J, O’Neal WK, Drumm ML, Durie PR, Knowles MR, Cutting GR: Genome-wide association and linkage identify modifier loci of lung disease severity in cystic fibrosis at $11 \mathrm{p} 13$ and 20q13.2. Nat Genet 2011;43:539-546.

90 Weiler CA, Drumm ML: Genetic influences on cystic fibrosis lung disease severity. Front Pharmacol 2013;4:40.

-91 Gaggar A, Chen J, Chmiel JF, Dorkin HL, Flume PA, Griffin R, Nichols D, Donaldson $\mathrm{SH}$ : Inhaled alpha1-proteinase inhibitor therapy in patients with cystic fibrosis. J Cyst Fibros 2016;15:227-233.

92 Chauhan B, Hutcheson PS, Slavin RG, Bellone CJ: MHC restriction in allergic bronchopulmonary aspergillosis. Front Biosci 2003; 8:s140-s148.
93 Jovanovic K, Siebeck M, Gropp R: The route to pathologies in chronic inflammatory diseases characterized by $\mathrm{T}$ helper type $2 \mathrm{im}$ mune cells. Clin Exp Immunol 2014;178:201211.

94 Ohashi W, Hattori K, Hattori Y: Control of macrophage dynamics as a potential therapeutic approach for clinical disorders involving chronic inflammation. J Pharmacol Exp Ther 2015;354:240-250.

95 Liu X, Zhan Z, Li D, Xu L, Ma F, Zhang P, Yao $\mathrm{H}$, Cao X: Intracellular MHC class II molecules promote TLR-triggered innate immune responses by maintaining activation of the kinase Btk. Nat Immunol 2011;12:416-424.

-96 Hofer TP, Frankenberger M, Heimbeck I, Burggraf D, Wjst M, Wright AK, Kerscher M, Nahrig S, Huber RM, Fischer R, Ziegler-Heitbrock L: Decreased expression of HLA-DQ and HLA-DR on cells of the monocytic lineage in cystic fibrosis. J Mol Med (Berl) 2014; 92:1293-1304.

97 Barr TA, Gray M, Gray D: B cells: programmers of CD4 T cell responses. Infect Disord Drug Targets 2012;12:222-231.
98 Siegmann N, Worbs D, Effinger F, Bormann $\mathrm{T}$, Gebhardt M, Ulrich M, Wermeling F, Muller-Hermelink E, Biedermann T, Tighe M, Edwards MJ, Caldwell C, Leadbetter E, Karlsson MC, Becker KA, Gulbins E, Doring G: Invariant natural killer T (iNKT) cells prevent autoimmunity, but induce pulmonary inflammation in cystic fibrosis. Cell Physiol Biochem 2014;34:56-70.

99 Bodas M, Vij N: The NF-kappaB signaling in cystic fibrosis lung disease: pathophysiology and therapeutic potential. Discov Med 2010; 9:346-356.

100 Hector A, Schafer H, Poschel S, Fischer A, Fritzsching B, Ralhan A, Carevic M, Oz H, Zundel S, Hogardt M, Bakele M, Rieber N, Riethmueller J, Graepler-Mainka U, Stahl M, Bender A, Frick JS, Mall M, Hartl D: Regulatory T-cell impairment in cystic fibrosis patients with chronic Pseudomonas infection. Am J Respir Crit Care Med 2015;191: 914-923.

101 Abu-El-Haija M, Ramachandran S, Meyerholz DK, Abu-El-Haija M, Griffin M, Giriyappa RL, Stoltz DA, Welsh MJ, McCray PB Jr, Uc A: Pancreatic damage in fetal and newborn cystic fibrosis pigs involves the activation of inflammatory and remodeling pathways. Am J Pathol 2012;181:499-507.

102 Munck A: Cystic fibrosis: evidence for gut inflammation. Int J Biochem Cell Biol 2014 52:180-183 